\title{
Statistics of the Universities of Great Britain.
}

$\mathrm{T}^{\mathrm{o}}$ the Returns * from Universities and University Colleges for the academic year 1929-30 the University Grants Committee prefixes an introductory note which serves to bring up to date the quinquennial review issued by the Committee last year and commented on at some length in NATuRE of Aug. 2, 1930.

The total number of full-time students, of both sexes, which increased by 7 per cent in the preceding five years, shows a further increase (to 45,603 ) of nearly 3 per cent; whilst the proportion of women students, which declined during those years from 31.4 to $29 \cdot 1$ per cent, shows a further drop to $28 \cdot 3$ per cent. The regional distribution of the increment registered in 1929-30 was : England 914 (879 men), Wales 96 (108 men), Scotland 245 ( 251 men). It is pointed out in the Committee's note that the figures for 1929-30 are swollen by the admission of 232 students to twoyear courses of training as teachers at university colleges, at the special request of the Board of Education, in view of the projected raising of the school age.

London has increased its lead as the university having the greatest number of full-time students (9141). The next twelve in order, Cambridge, Glasgow, Oxford, Edinburgh, Wales, Manchester, Liverpool, Durham, Leeds, Birmingham, Aberdeen, Bristol, show no change in their relative positions in this respect. All universities except Aberdeen and Reading show some increase.

The number of full-time students from hornes outside the British Isles was 4573 , being 10 per cent of the total and 4 per cent more than in the preceding year. More than one-third of these are from foreign countries, and the number of such foreign students tends to increase somewhat rapidly. It increased by 26 per cent in the five years 1923-29, and by 9 per cent from 1928-29 to 1929-30. The corresponding increases in the numbers of students from countries in the British Empire beyond the British Isles were 14 per cent in the five years $1923-29$ and only $1 \cdot 3$ per cent in the following year. Why the pull of the home universities is waning in these countries while waxing in foreign countries is a question on which light could perhaps be thrown by the delegates who are to meet at Edinburgh in July in the fourth Congress of the Universities of the Empire. The universities which have the largest numbers of students from countries within the Empire outside the British Isles are London (1060), Edinburgh (456), Cambridge (352), Oxford (296), Glasgow (177), and Manchester (79). In addition to full-time students, there were 653 parttime students whose homes were outside the British

* University Grants Committee. Returns from Universities and University Colleges in receipt of Treasury Grant, Academic Year 1929-1930. Pp. 22. (London: H.M. Stationery Office, 1931.) 1s. 3d.
Isles but within the Empire, and 852 foreign parttime students.

The distribution of the full-time students among the various subject groups in 1929-30 was: arts, 53.4 per cent; medicine, 19.1 ; pure science, 16.5 ; technology, $9 \cdot 1$; agriculture, $I \cdot 9$. This shows but little variation from the preceding year's distribution. The decline in the number of men medical students, which had been continuous since 1923-24, was arrested in 1928-29, when there was an increase of 205 , which was followed by a further increase in 1929-30 of 310 . The similar decline in the number of women medical students continued down to 1929-30, when there was a small increase, from 1108 to 1136 .

Full-time advanced students numbered 2128 , of whom 1763 were men, an increase of 46 (men 55). The greater number of these students were at work at Cambridge (355), University College, London (228), Imperial College of Science, London (227), King's College, London (123), London School of Economics (121), Oxford (172), and Edinburgh (133). Their distribution among the various subject groups was as follows : mathematics and pure science, $42 \cdot 4$ per cent; arts, 39.2 per cent ( 35 per cent of the men and 58 per cent of the women); technology, 11.5 per cent; medicine, $4 \cdot 7$ per cent; agriculture, $2 \cdot 2$ per cent. Chemistry, including applied chemistry and biochemistry, claimed 487 students, engineering 216 , physies 140, botany 87 . In addition to these fulltime students, 1683 part-time students (1351 men and 332 women) were engaged in advanced work.

A table showing the numbers of full-time staffs employed in the teaching departments gives the following totals : professors, 798 ; readers, assistant professors, and independent lecturers, 334 ; lecturers, 1147 ; assistant lecturers and demonstrators, 827 ; and others, 243. The number of lecturers is somewhat understated owing to the Oxford and Cambridge returns excluding lecturers holding no full-time university appointment, many of whom actually devote their whole time to teaching. Omitting Oxford and Cambridge, the table shows that for the instruction of every hundred full-time students there were available, on an average, the following full-time teachers : professors, 2 ; readers, etc., 0.9 ; lecturers, $3 \cdot 3$; assistant lecturers and demonstrators, $2 \cdot 1$; and other teachers, 0.7--total, 9. Taking England alone, exclusive of Oxford and Cambridge, the ratio of full-time teaching staff to full-time students was 10.8 per cent; in London alone it was 9 , in Wales 11 , and in Scotland $5 \cdot 7$.

Statements of income and expenditure show totals of $£ 5,338,064$ and $£ 5,280,530$ respectively. Commenting on these accounts, the Committee observes that of the fifty-two institutions included in the returns, only two or three show deficits representing any serious financial weakness.

\section{Second International Congress of the History of Science and Technology.}

Y $E N$ of science from all parts of the world who are 1 interested in the history and evolution of their subjects will be meeting at the Second International Congress of the History of Science and Technology to be held in London on June 29-July 4 under the presidency of Dr. Charles Singer. The Congress is held under the auspices of the Comité International d'Histoire des Sciences, with the collaboration of the Comité International des Sciences Historiques, the
Newcomen Society for the Study of the History of Engineering and Technology and the History of Science Society. Inquiries concerning membership and meetings of the Congress should be addressed to one of the honorary secretaries, Mr. H. W. Dickinson, or Mr. Walter Adams, The Science Museum, South Kensington.

The Government is showing great interest in the Congress. The President of the Board of Education,

No. 3214, VoL. 127] 